\title{
Influence of voltage reserve on the parameters of parallel power active compensators in mining
}

\author{
Andrii Kolb ${ }^{1}$, Yuliya Pazynich ${ }^{2 *}$, Adam Mirek ${ }^{3}$, and Oksana Petinova ${ }^{4}$ \\ ${ }^{1}$ Dnipro University of Technology, Department of Electrical Engineering, 19 Yavornytskoho Ave., \\ 49005 Dnipro, Ukraine \\ ${ }^{2}$ Dnipro University of Technology, Department of Philosophy and Pedagogy, 19 Yavornytskoho Ave., \\ 49005 Dnipro, Ukraine \\ ${ }^{3}$ State Mining Authority, 31 Poniatowskiego St., 40-055 Katowice, Poland \\ ${ }^{4}$ South Ukrainian National Pedagogical University named after K.D. Ushynsky, Department of \\ Philosophy, Sociology and Management, 26 Staroportofrankivska St., 65020 Odesa, Ukraine
}

\begin{abstract}
The static and dynamic reserve of voltage in input of voltage autonomous inverter being a component of parallel power active compensator on the physical realizability of inactive current components with the determined response, pulsations amplitude and commutation frequency of invertor switches was considered. Invariance of closed system of automated power quality regulation with relay control to the parametric and external disturbances is provided by the dynamic voltage reserve calculated from the obtained expressions. Special attention is given to the possibility of using this system in mining. Proposed approaches also can be used in the training of engineers in the electrical and mining industries.
\end{abstract}

\section{Introduction}

A mining enterprise is a complex technical and technological system that depends on the consistency of its constituent elements. This situation is typical for mines of any form of ownership and equipment support applied to all technological processes [1 - 4]. In this system, the reliability of the mine energy network, its efficiency and stability affect all production stages. Ultimately, in addition to ensuring the efficiency of the enterprise, ventilation, and safety, it also significantly affects the cost of mining [2, 4-8].

This is especially relevant for power energy consumers regardless to their location and the peculiarities of mining processes. Improvement of control system for fuel and energy complex and energy saving process is among the important state purposes. Energy saving is aimed at reasoned use of fuel and gas resources and includes a complex of measures for the structure of energy sources consumption, implementation of modern energy saving technology, deeper extraction of useful components, use of secondary resources, energy consumption control, and development of nontraditional and renewable energy system. Energy efficiency, as a problem of fuel and energy complex, as well as the ability of the latter to provide the efficient functioning of the whole economic system, is one of the

\footnotetext{
* Corresponding author: jpazynich@ukr.net
} 
determining factors of national economy [7, 9-11].

Electric drives consume the biggest part of generated power. That is the reason for the issues of complex approach to the development and practical application of ways of energy saving and flexible management of traditional indicators of power quality using the means of industrial electric drive becoming of great importance.

The systems of group power supply for electric drives with capacitors equipped with parallel power active compensators (PPAC) enable energy accumulation of regeneration braking of a single motor or motors group. The energy may also be reused in power supply of motor operation drives with the efficient power quality control of nonlinear and unbalanced systems with abruptly variable reactive load [7, 9, $12-15]$.

PPAC relay control for normalization of traditional quality indicators of power enables implementation of maximum permissible system response speed and high control accuracy resulting from forced influence on a controlled object. This requires the system to have the needed power resource, namely static and dynamic reserve (storage) of voltage in DC link, which being inverted forms altering voltage of a needed value in power inputs of voltage autonomous inverter.

Kink width of current relay regulators (CRR) is chosen as middle-ground of current pulsations amplitude and commutation frequency of invertor switches characterizing the capacity losses.

The aim of the paper is to analyze the influence of static and dynamic voltage reserve in invertor input on physical realizability of compensation modes of inactive current components with the determined response, pulsations amplitude and commutation frequency of invertor switches depending on the location of the power consumer in the mine.

\section{Materials and research results}

The authors $[1-4,16-18]$ quite fully consider the technological schemes and methods of production processes in mining. The attention is paid to thermodynamic processes that are formed during the introduction of various non-traditional mining technologies [17, $19-27]$. Much attention is also paid to the utilization of waste from mining and related activities and the introduction of information technology in of mining processes [22, 23, 28 - 36].

Considerable attention is also paid to the power supply of mining enterprises and the efficiency of its work paper [7, 8, $13-15,37-42]$. The paper [14] describes the system of group power supply for drives with diode rectifier and capacitive storage equipped with one or more PPAC. This enables not only compensation of inactive current components and maintenance of optimum power factor at transformer output, but also line losses minimization by means of compensators hooking up in the assemblies of maximum reactive load. If the optimum mode at transformer output is only required (without line losses compensation), then the system of group power supply for drives with capacitive storages described in [14] may be represented in the form shown at Fig.1. The diode rectifier and voltage autonomous inverter plugged according to reverse mode are connected in parallel via $L$ choke forming a complex active rectifier.

Determining and direct control of transient values of inactive components of gross output in the given framework is implemented on the base of $I_{x}, I_{y}$ method of instantaneous power theory using generalized (resulting) phasors of current and voltage in synchronous rotating coordinate system with $x$ axis oriented in accordance with network voltage phasor. This is the reason for using phase and coordinate converters implemented with respect to known correlations [38] in the framework (Fig.1). The variable component $I_{x \sim}$ occurring only in nonlinear and unbalanced systems is distinguished from orthogonal component $I_{x}$ of proportional active power by means of high frequency filter $\Phi$. 


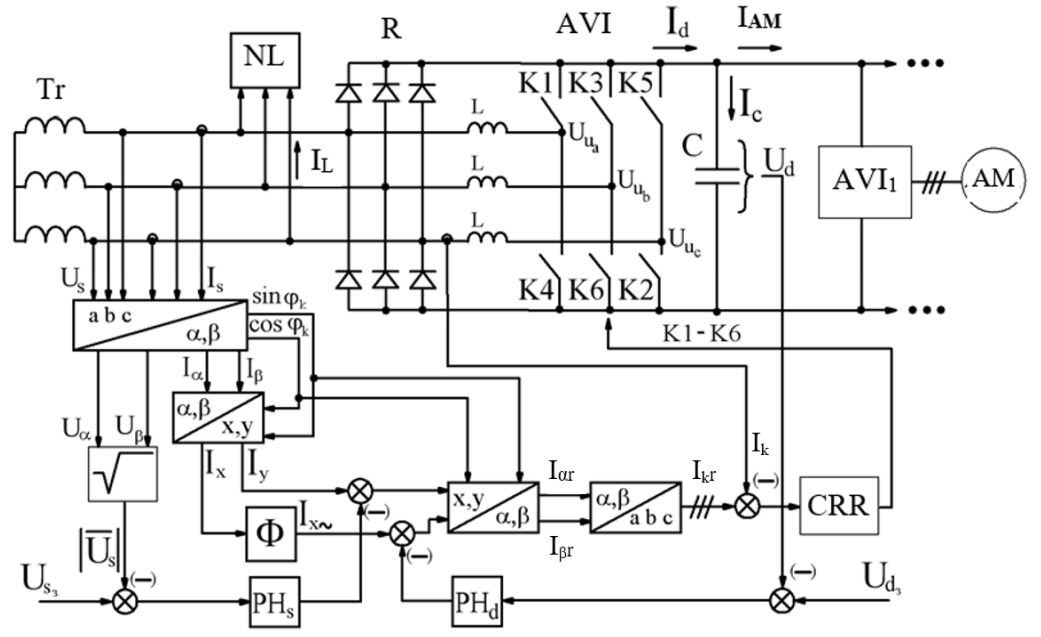

Fig. 1. Functional framework of complex active rectifier.

Modulating by the method of high frequency PWM the voltage value and phase at voltage autonomous inverter input it is possible to provide almost simple harmonic current of network with the required power factor of close or equal to one value. In case the only variable components $I_{x \sim}$ and $I_{y \sim}$ without double frequency components are supplied to inverter input, the PPAC operates as a compensator (filter) for higher harmonics [14].

In the load balance mode power in transferred from less loaded phases to DC link and then to more loaded phases by means of PPAC. The mode is obtained by means of supply of only variable components $I_{x \sim}$ and $I_{y \sim}$ of double frequency to coordinates inverter (CI) input.

The operation principle of PPAC based on diode amplifier with AVI of PWM consists in that it generates current into a network; the current equals to the sum of opposite in phase currents of higher harmonics and load reactive current. As a result, PPAC combined with nonlinear and unbalanced load is almost active load for a network. In the framework (Fig. 1) the type of network current is varied (reactive or capacitive) by means of network voltage controller (PHs), and this also the way of voltage stabilization for load in case of high-response control system existence. Furthermore, if the voltage on load is reduced, the current in the network becomes of capacitive type and vice versa.

The voltage regulator $(\mathrm{PHd})$ influencing the active current component $I_{x}$, maintains the outlined voltage in DC link.

To analyse the set and transient modes in the system for high commutation frequency of invertor switches it is efficient to use the equivalent model resulting from continuous approximation of its discrete commutation function. In the case in the $\alpha, \beta$ set coordinate system the PAC voltages equation is described in generalized vectors by means of known equation

$$
\bar{U}_{u(\alpha, \beta)}+\bar{U}_{S(\alpha, \beta)}=\bar{I}_{k(\alpha, \beta)} R+L \frac{d \bar{I}_{k(\alpha, \beta)}}{d t}
$$

where $\bar{U}_{u(\alpha, \beta)}, \bar{U}_{S(\alpha, \beta)}, \bar{I}_{k(\alpha, \beta)}$ are stand for generalized voltages phasors of invertor, network and compensation current in the set coordinate system $\alpha, \beta ; R$ are stands for resistances sum of compensation circuit, transformer windings and losses on switches; $L$ is 
stands for total inductance including filter inductance $L_{f}$ and leak inductance of transformer windings.

The turn to the rotating system of coordinates $x, y$ creates additional advantages, namely simplifies regulators synthesis, since in such a case the harmonic variables are transformed into the corresponding orthogonal components. The turn from one system of coordinates to another is provided my means of the known correlations:

$$
\bar{U}_{(\alpha, \beta)}=\bar{U}_{(x, y)} e^{j \phi_{k}} ; \bar{U}_{(x, y)}=\bar{U}_{(\alpha, \beta)} e^{-j \phi_{k}},
$$

where $\varphi_{k}$ is stands for angle between coordinate axes.

As based on the expression (2) from the formula (1) in synchronous rotating system of coordinates ( $x, y$ indices are omitted) we may note:

$$
\bar{U}_{u} e^{j \phi_{k}}+\bar{U}_{s} e^{j \phi_{k}}=R \bar{I}_{k} e^{j \phi_{k}}+L \frac{d\left(\bar{I}_{k} e^{j \phi_{k}}\right)}{d t}
$$

where $\omega=d \varphi_{k} / d t$ stands for angular velocity of coordinate axes, which is equal to pulsation $\omega=2 \pi f$ of supply voltage.

Differentiating the expression (3) and reducing by $e^{j \varphi k}$ we obtain the system equation in vector form in synchronous rotating system of coordinates $x, y$ :

$$
\bar{U}_{u}+\bar{U}_{s}=R \bar{I}_{k}+L \frac{d \bar{I}_{k}}{d t}+j \omega L \bar{I}_{k}
$$

Turning to the orthogonal components in synchronous rotating system of coordinates oriented in accordance with network voltage phasor we obtain:

$$
\begin{aligned}
& U_{u x}+U_{s x}=R I_{k x}+L \frac{d I_{k x}}{d t}-L \omega I_{k y} ; \\
& U_{u y}+U_{s y}=R I_{k y}+L \frac{d I_{k y}}{d t}+L \omega I_{k x} .
\end{aligned}
$$

In the set periodical mode (stability of compensated reactive power) currents derivatives in (5) and (6) equal to zero and static voltage reserve on $x$, and $y$ axes for smooth current component is determined as:

$$
\begin{aligned}
& \Delta \bar{U}_{x}=U_{u x}+U_{s x}=I_{k x} R-\omega_{k} L I_{k y} \\
& \Delta \bar{U}_{y}=U_{u y}+U_{s y}=I_{k y} R+\omega_{k} L I_{k x} .
\end{aligned}
$$

Considering the expressions (7) for smooth current components (continuous model) it is possible to formulate the physical realizability condition of compensation mode of reactive power $Q$ in the form of voltage static reserve (storage) in inputs of voltage autonomous inverter with modulus:

$$
\Delta U_{s t}=\sqrt{\left(I_{k x} R-\omega L I_{k y}\right)^{2}+\left(I_{k y} R+\omega L I_{k x}\right)^{2}}=I_{k} Z \approx I_{s y} Z,
$$

where $Z=\sqrt{R^{2}+(\omega L)^{2}}$ stands for total resistance of compensation circuit; $I_{s y}$ stands for reactive component of network current.

Three-dimensional position $\Delta \psi$ of vector $\Delta \bar{U}_{s t}$ according to (7) is determined as: 


$$
\Delta \psi=\operatorname{arctg} \frac{I_{k y} R+\omega L I_{k x}}{I_{k x} R-\omega L I_{k y}} .
$$

As a rule, $I_{k x} R<<\omega L I_{k y}$ so the denominator in equation (9) will be negative, and consequently the angle $\Delta \psi$ is beyond the limits $\pi / 2<\psi<\pi$, since $\sin \Delta \psi>0$, and $\cos \Delta \psi<0$.

With respect to the abovementioned correspondences the vector PAC diagram of voltages and currents is drawn at Fig. 2 in the mode of reactive power compensation and active power consumption for system losses compensation. From the scheme it is clear that the resulting vector of invertor voltage $\bar{U}_{u}=\bar{U}_{s}-\Delta \bar{U}_{s t}$ in the mode lags from $\bar{U}_{u}$ on $\phi_{u}$ angle determined as:

$$
\phi_{u}=\operatorname{arctg} \frac{I_{k y} R+\omega L I_{k x}}{U_{s}+I_{k x} R-I_{k x} \omega L} .
$$

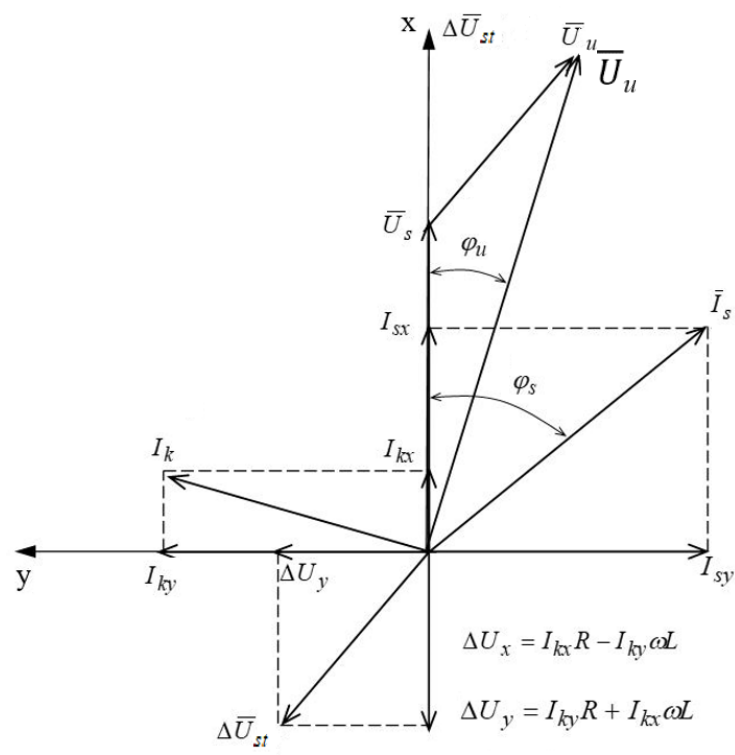

Fig. 2. Vector diagram of voltages and currents in compensation mode of reactive power and active power consumption.

Currents components $I_{k y}$ and $I_{k x}$ in the equation (10) may be expressed via reactive power $Q$ to be compensated. In the synchronous rotating system of coordinates oriented in accordance with resulting vector of network voltage is $Q=\frac{3}{2} U_{s} I_{s y}$ [14]. From which not considering the system losses:

$$
I_{s y}=I_{k y}=2 Q / 3 U_{s} .
$$

Setting total losses in the system $\Delta P=\frac{3}{2} I_{k}^{2} R$ equal to power consumed form the network for the losses compensation $\Delta P_{s}=\frac{3}{2} U_{s} I_{k x}$, we obtain:

$$
I_{k x}=I_{k}^{2} R / U_{s} \approx I_{s y}^{2} R / U_{s}
$$


According to the expressions (8) - (12) we get:

$$
\begin{aligned}
& \Delta U_{s t}=\frac{2 Q Z}{3 U_{s}} ; \\
& \phi_{u}=\operatorname{arctg} \frac{U_{s} I_{s y} R+\omega L I_{s y}^{2} R}{U_{s}^{2}+R^{2} I_{s y}^{2}-U_{s} I_{s y} \omega L} .
\end{aligned}
$$

The dynamic voltage reserve $\Delta U_{d}$ needed only for realization of required commutation frequency of switches in the determined current pulsation amplitude may be determined on the base of curves analysis of compensation current change $i_{k}$ under the conditions of unbalanced periodical mode (Fig. 3) being described by exponents jogs.

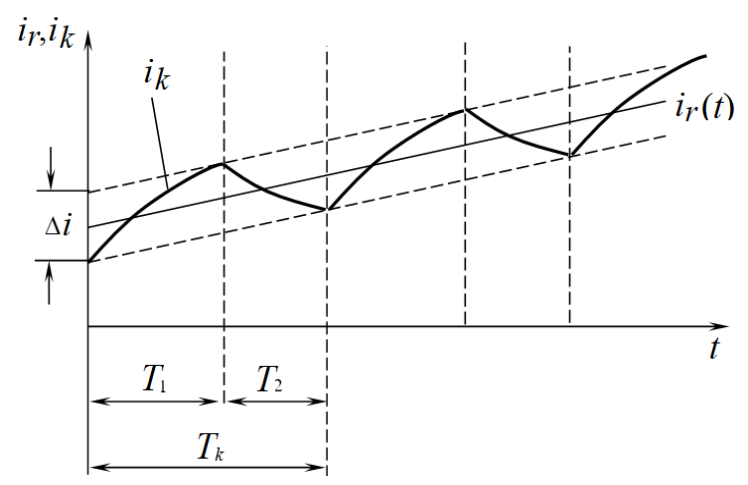

Fig. 3. Graphs of compensation current changes $i_{k}$ in relay control systems.

For time interval $0 \leq t \leq T_{1}$ :

$$
i_{k 1}=\frac{U_{\Sigma}}{R}\left(1-e^{-t / T}\right)-\left(i_{r}(t)-\frac{\Delta i}{2}\right) e^{-t / T} ;
$$

For time interval $0 \leq t \leq T_{2}$ :

$$
i_{k 2}=-\frac{U_{\Sigma}}{R}\left(1-e^{-t / T}\right)+\left(i_{r}(t)+\frac{\Delta i}{2}\right) e^{-t / T},
$$

where $T=L / R$ stands for electromagnetic time constant of a circuit; $\Delta i$ flux current loop width of current relay controller; $U_{\Sigma}$ modulus of the vector resulting voltages $\bar{U}_{\Sigma}=U_{u} e^{j \phi_{u}}-U_{S} e^{j \phi_{s}}$.

$T_{1}$ semiperiod is finished when compensation current reaches the value of $i_{k}=i_{r}+\Delta i / 2$, and $T_{2}$ semiperiod is finished when $i_{k}=i_{r}-\Delta i / 2$. Considering this the expressions for $T_{1}$ and $T_{2}$ semiperiods calculation are as follows:

$$
\begin{aligned}
& i_{r}(t)+\Delta i / 2=\frac{U_{\Sigma}}{R}\left(1-e^{-T_{1} / T}\right)-\left(i_{r}(t)-\frac{\Delta i}{2}\right) e^{-T_{1} / T} \\
& i_{r}(t)-\Delta i / 2=-\frac{U_{\Sigma}}{R}\left(1-e^{-T_{2} / T}\right)+\left(i_{r}(t)+\frac{\Delta i}{2}\right) e^{-T_{2} / T} .
\end{aligned}
$$


The frequency of commutation of PAC invertor switches depends on both scheme parameters and current transient value and its derivative. The analytic determination of commutation period in such a case is very difficult and may be determined using numerical methods. If $i_{r}(t)=I_{r}=$ const, then in accordance with the expressions (16) and (17) the equation of commutation period $T_{k}$ is as follows:

$$
T_{k}=T_{1}+T_{2}=T \ln \frac{I_{m}+\Delta i-I_{r}^{2} / I_{m}}{I_{m}-\Delta i-I_{r}^{2} / I_{m}}=T \ln \left(1+\frac{\Delta i}{I_{m}}-\frac{I_{r}^{2}}{I_{m}^{2}}\right) /\left(1-\frac{\Delta i}{I_{m}}-\frac{I_{r}^{2}}{I_{m}^{2}}\right)
$$

or

$$
T_{k}=T \ln \left(\frac{I_{m}}{I_{r}}+\frac{\Delta i}{I_{r}}-\frac{I_{r}}{I_{m}}\right) /\left(\frac{I_{m}}{I_{r}}-\frac{\Delta i}{I_{r}}-\frac{I_{r}}{I_{m}}\right),
$$

where $I_{m}=U_{\Sigma} / R$ stands for current settling value.

The graphs of functions $T_{k} / T=f\left(I_{m} / I_{r . m}\right)$ for different values of current pulsation coefficient $K_{i}=\Delta i / I_{r . m}$, drawn with respect to the equation (19) are shown at Fig. 4.

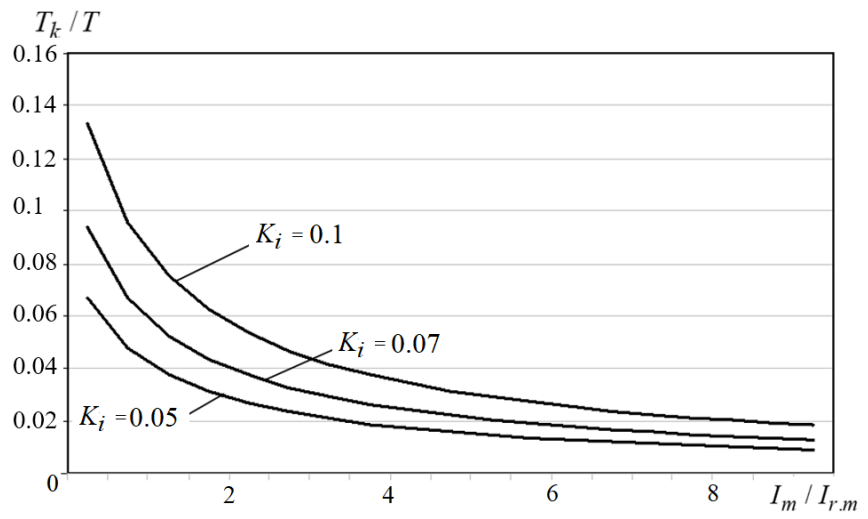

Fig. 4. Dependence $T_{k} / T=f\left(I_{m} / I_{r, m)}\right.$ for different values of current pulsation coefficient $K_{i}$ PAC.

In case of simple harmonic current of reference $i_{r}=I_{r . m} \sin \omega t$ peculiar to the systems controlled on the base of transient values of inactive components of total power, the commutation period is without serious error determined from the expression:

$$
T_{k}=T \ln \frac{\frac{I_{m}}{I_{r . m}}+\frac{\Delta i}{I_{r . m}}-\frac{I_{r . m} \sin ^{2} \psi}{I_{m}}}{\frac{I_{m}}{I_{r . m}}-\frac{\Delta i}{I_{r . m}}-\frac{I_{r . m} \sin ^{2} \psi}{I_{m}}},
$$

where $\psi$ is stands for initial phase of reference current.

Considering only two term of series in equation (18) we obtain the approximate expression of commutation period of invertor switches for $I_{r}=$ const :

$$
T_{k}=\frac{2 T \Delta i}{I_{m}}\left(1+\frac{I_{r}^{2}}{I_{m}^{2}}\right)=\frac{2 T K_{i} I_{r}}{I_{m}}\left(1+\frac{I_{r}^{2}}{I_{m}^{2}}\right) .
$$


For simple harmonic current of reference

$$
T_{k}=\frac{2 T K_{i} I_{r \cdot \max }}{I_{m}}\left(1+\frac{I_{r . m}^{2} \sin ^{2} \psi}{I_{m}^{2}}\right)
$$

The expression (18) determining of minimum pulsation coefficient of invertor current $K_{i}=\Delta i / I_{r . m}$, and consequently the maximum width of hysteresis band $\Delta i_{\max }$ of relay current controller with respect to the permissible commutation frequency of invertor switches for set parameters of compensation circuit.

$$
K_{i}=\frac{T_{k}}{2 T \frac{I_{r . m}}{I_{m}}\left(1+\frac{I_{r . m}^{2}}{I_{m}^{2}}\right)} ; \Delta i=\frac{T_{k} I_{m}}{2 T\left(1+\frac{I_{r . m}^{2}}{I_{m}^{2}}\right)} .
$$

The transformed expression (21)

$$
U_{\Sigma}^{2}\left(T_{k} U_{\Sigma}-2 L K_{i} I_{r . m}\right)=2 L K_{i} I_{r}^{3} R^{2}
$$

shows that minimum dynamic reserve of voltage input of voltage autonomous inverter providing the reproduction of reference current of required pulsation amplitude (quick response in small) comprises:

$$
\Delta U_{\partial . \min }>\frac{2 L K_{i} I_{r . m}}{T_{k}}=\frac{2 L \Delta i}{T_{k}},
$$

i.e. for set circuit inductivity $\Delta U_{\partial \text {.min }}$ is proportional to the width of CRR flux current loop and commutation frequency $f_{k}=1 / T_{k}$ of invertor switches.

Dynamic voltage reserve needed for realization of required time of the first sequence $t_{p}$ in the closed system for reactive power surge is determined by the second components of the right parts of the equations (5) and (6). Considering the set time of the first sequence the components in $x, y$ axes are determined as:

$$
\begin{aligned}
& \Delta U_{\partial x}^{\prime}=L \frac{d I_{k x}}{d t}=\frac{L I_{k x}}{t_{p}}=\frac{R L I_{s y}^{2}}{U_{S} t_{p}} \\
& \Delta U_{\partial y}^{\prime}=L \frac{d I_{k y}}{d t}=\frac{L I_{k y}}{t_{p}}=\frac{L I_{s y}}{t_{p}} .
\end{aligned}
$$

On the base of the expressions the modulus of voltage dynamic reserve in invertor input required for realization of set response in large is:

$$
\Delta U_{\partial}^{\prime}=\sqrt{\Delta U_{\partial x}^{\prime 2}+\Delta U_{\partial y}^{\prime 2}}=\frac{L I_{s y}}{t_{p}} \sqrt{1+\frac{R I_{s y}}{U_{s}}}=\frac{2 L Q}{3 U_{s} t_{p}} \sqrt{1+\frac{R I_{s y}}{U_{s}}} .
$$

Total voltage reserve $U_{\Sigma}$ is determined by geometric sum of voltages calculated by means of (8), (25) and (28) comprises:

$$
\bar{U}_{\Sigma}=U_{\Sigma} x+j U_{\Sigma} y=\left(I_{k x} R-\omega L I_{s y}-\frac{2 L \Delta i}{T_{k}}+\frac{L I_{k x}}{t_{p}}\right)+j\left(I_{k y} R+\omega L I_{k x}+\frac{2 L \Delta i}{T_{k}}+\frac{L I_{s y}}{t_{p}}\right) .
$$


Using relations (11) and (12) comprising $I_{s y}$ and $I_{k x}$ in the expression (29) may be substituted by corresponding value of reactive power to be compensated.

For the purpose of system synthesis the closed current circuit with relay controllers may be shown as the aperiodic link

$$
W_{T(p)}=\frac{I_{k}(p)}{I_{r}(p)}=\frac{1}{T_{e} p+1} .
$$

With equivalent time constant $T_{e}=T \Delta U_{s t} / \Delta U_{\partial}^{\prime}+\Delta U_{s t}$, (where $U_{s t}$ and $\Delta U_{\partial}^{\prime}$ are determined from (8) and (28) obtained from change analysis of current in the circuit $R, L$, in case of absence and presence of dynamic voltage reserve.

\section{Conclusions}

This is extremely important in the power supply of mines, as the grouping of individual consumers makes it possible to establish the reserve in the electricity consumption system; set peak loads on the network with their subsequent redistribution to maximize the efficiency of production. The obtained expressions enable determination of static and dynamic reserves of voltage in DC link for physical realizability of compensation process of reactive power with the determined response, current pulsation level and commutation frequency of invertor switches.

Each mine as a production system has a significant reserve for redistribution of power supply. The dynamic voltage reserve calculated from the obtained expressions provides invariance of closed system of automated system of power quality regulation with relay control to the parametric and external disturbances.

\section{References}

1. Pivnyak, G., Dychkovskyi, R., Smirnov, A., \& Cherednichenko, Y. (2013). Some aspects on the software simulation implementation in thin coal seams mining. Energy Efficiency Improvement of Geotechnical Systems, 1-10. https://doi.org/10.1201/b16355-2

2. Tor, A. (Ed.). (2011). New Techniques and Technologies in Thin Coal Seam Exploitation. https://doi.org/10.1201/b11749

3. Sribna, Y., Trokhymets, O., Nosatov, I., \& Kriukova, I. (2019). The globalization of the world coal market - contradictions and trends. E3S Web of Conferences, (123), 01044. https://doi.org/10.1051/e3sconf/201912301044

4. Pivnyak, G., Dychkovskyi, R., Bobyliov, O., Cabana, E. C., \& Smoliński, A. (2018). Mathematical and Geomechanical Model in Physical and Chemical Processes of Underground Coal Gasification. Solid State Phenomena, (277), 1-16. https://doi.org/10.4028/www.scientific.net/ssp.277.1

5. Dychkovskyi, R.O., Avdiushchenko, A.S., Falshtynskyi, V.S., \& Saik, P.B. (2013). On the issue of estimation of the coal mine extraction area economic efficiency. Naukovyi Visnyk Natsionalnoho Hirnychoho Universytetu, (4), 107-114.

6. Piwniak, G.G., Bondarenko, V.I., Salli, V.I., Pavlenko, I.I., \& Dychkovskiy, R.O. (2007). Limits to economic viability of extraction of thin coal seams in Ukraine. Technical. Technological and Economic Aspects of Thin-Seams Coal Mining International Mining Forum 2007, 129-132. https://doi.org/10.1201/noe0415436700.ch16

7. Pivnyak, G.G., Sobolev, V.V., \& Filippov, A.O. (2012). Phase transformations in bituminous coals under the influence of weak electric and magnetic fields. Naukovyi Visnyk Natsionalnoho Hirnychoho Universytetu, (5), 43-49.

8. Pivnyak, G., Razumny, Y., \& Zaika, V. The problems of power supply and power saving in the mining industry of Ukraine. Archives of Mining Sciences, 54(1), 5-12. 
9. Pazynich, Yu., Kolb, A., \& Potempa, M. (2017). Implementation of Energy Safety Policy in Ukraine by Means of Energy Saving in Electric Drive Systems. Advanced Engineering Forum, (25), 96-105. https://doi.org/10.4028/www.scientific.net/AEF.25.96

10. Golovchenko, A, Pazynich, Yu. Potempa, M. (2018). Automated Monitoring of Physical Processes of Formation of Burden Material Surface and Gas Flow in Blast Furnace. Solid State Phenomena, (277), 54-65. https://doi.org/10.4028/www.scientific.net/SSP.277.54

11. Pazynich, Yu.M. (2014) Vykorystannia ihfomatsiinykh tekhnolohii navchannia v suchasnii systemi osvity, 88-90. Retrieved from http://ir.nmu.org.ua/bitstream/handle/123456789/147971/8890.pdf? sequence $=1$

12. Kolb, A. (2013). Energy saving in electrified transport by capacity storages. Energy Efficiency Improvement of Geotechnical Systems. International Forum on Energy Efficiency (pp. 121-124).

13. Dreus, A.Yu., Sudakov, A.K., Kozhevnikov, A.A., Vakhalin, Yu.N. (2016). Study on thermal strength reduction of rock formation in the diamond core drilling process using pulse flushing mode. Naukovyi Visnyk Natsionalnoho Hirnychoho Universytetu, (3), 5-10.

14. Kolb, A.A. (2008). Kompensatsiya reaktivnoy moshchnosti v elektroprivodakh s emkostnymi nakopitelyami. Efektyvnist ta Yakist Elektropostachannia Promyslovykh Pidpryiemstv, 232-235.

15. Kolb, A.A. (2008). K raschetu napryazheniya $\mathrm{v}$ zvene postoyannogo toka silovykh aktivnykh kompensatorov v sistemakh gruppovogo pitaniya privodov. Visnyk Kremenchutskoho Derzhavnoho Politekhnichnoho Universrytetu, 4(51), 37-41.

16. Kopacz, M., Sobczyk, E.J., \& Galica, D. (2018). The impact of variability and correlation of selected geological parameters on the economic assessment of bituminous coal deposits with use of non-parametric bootstrap and copula-based Monte Carlo simulation. Resources Policy, (55), 171-183. https://doi.org/10.1016/j.resourpol.2017.11.015

17. Dychkovskyi, R., Vladyko, O., Maltsev, D., \& Cáceres Cabana, E. (2018). Some aspects of the compatibility of mineral mining technologies. Rudarsko Geolosko Naftni Zbornik, 33(4), 73-82. https://doi.org/10.17794/rgn.2018.4.7

18. Saługa, P.W., Sobczyk, E.J., \& Kicki, J. (2015). Wykazywanie zasobów wêgla kamiennego w Polsce zgodnie z JORC Code/Reporting of Hard Coal Reserves and Resources in Poland on the Basis of the JORC Code. Gospodarka Surowcami Mineralnymi, 31(2), 5-29. https://doi.org/10.1515/gospo-2015-0019

19. Tabachenko, N.M., Dychkovskiy, R.Ye., \& Falshtynskiy, V.S. (2012). About extraction of methane and slate gas from coal and slate deposits. Naukovyi Visnyk Natsionalnoho Hirnychoho Universytetu, (2), 44-48.

20. Pivnyak, G., Dychkovskyi, R., Cabana, E.C, Lozynskyi, V., \& Saik, P. (2020). Actual Challenges in Materials Science and Processing Technologies (Preface). Key Engineering Materials, (844). https://doi.org/10.4028/www.scientific.net/KEM.844

21. Nazarova, O., Osadchyy, V., \& Shulzhenko, S. (2019). Accuracy Improving of the Two-Speed Elevator Positioning by the Identification of Loading Degree. 2019 IEEE International Conference on Modern Electrical and Energy Systems (MEES). https://doi.org/10.1109/mees.2019.8896414

22. Petlovanyi, M.V., Lozynskyi, V.H., Saik, P.B., \& Sai, K.S. (2018). Modern experience of lowcoal seams underground mining in Ukraine. International Journal of Mining Science and Technology, 28(6), 917-923. https://doi.org/10.1016/j.ijmst.2018.05.014

23. Golovchenko, A., Dychkovskyi, R., Pazynich, Y., Edgar, C.C., Howaniec, N., Jura, B., \& Smolinski, A. (2020). Some Aspects of the Control for the Radial Distribution of Burden Material and Gas Flow in the Blast Furnace. Energies, 13(4), 923. https://doi.org/10.3390/en13040923

24. Dychkovskyi, R.O. (2015). Determination of the rock subsidence spacing in the well underground coal gasification. Naukovyi Visnyk Natsionalnoho Hirnychoho Universytetu, (6), 30-36.

25. Lozynskyi, V.H., Dychkovskyi, R.O., Falshtynskyi, V.S., \& Saik, P.B. (2015). Eksperymentalni doslidzhennia vplyvu perekhodu dyziunktyvnoho heolohichnoho porushennia na temperaturnyi rezhym pidzemnoho hazoheneratora. Naukovyi Visnyk NHU, (4), 22-28. 
26. Law, B.E., Ulmishek, G.F., Clayton, J.L., Kabyshev, B.P., Pashova, N.T., \& Krivosheya, V.A. (1998). Basin-centered gas evaluated in Dnieper-Donets basin, Donbas foldbelt, Ukraine. Oil and Gas Journal, 96(47), 74-78.

27. Buzylo, V., Yavorsk'yy, A., \& Yavorsk'yy, V. (2012). Analysis of stress-strain state of rock mass while mining chain pillars by chambers. Geomechanical Processes During Underground Mining Proceedings of the School of Underground Mining, 95-98. https://doi.org/10.1201/b13157-16

28. Babets, D., Sdvyzhkova, O., Shashenko, O., Kravchenko, K., \& Cabana, E.C. (2019). Implementation of probabilistic approach to rock mass strength estimation while excavating through fault zones. Mining of Mineral Deposits, 13(4), 72-83. https://doi.org/10.33271/mining13.04.072

29. Shashenko, A., Gapieiev, S., Solodyankin, A. (2009). Numerical simulation of the elastic-plastic state of rock mass around horizontal workings. Archives of Mining Sciences, 54(2), 341-348.

30. Falshtynskyi, V., Saik, P., Lozynskyi, V., Dychkovskyi, R., \& Petlovanyi, M. (2018). Innovative aspects of underground coal gasification technology in mine conditions. Mining of Mineral Deposits, 12(2), 68-75. https://doi.org/10.15407/mining12.02.068

31. Sobolev, V. (2020). Reasons for breaking of chemical bonds of gas molecules during movement of explosion products in cracks formed in rock mass. International Journal of Mining Science and Technology, 30(2), 265-269. https://doi:10.1016/j.ijmst.2020.01.002

32. Dychkovskyi, R., Tabachenko, M., Zhadiaieva, K., \& Cabana, E. (2019). Some aspects of modern vision for geoenergy usage. E3S Web of Conferences, (123), 01010. https://doi.org/10.1051/e3sconf/201912301010

33. Gorova, A., Pavlychenko, A., \& Borysovs'ka, O. (2013). The study of ecological state of waste disposal areas of energy and mining companies. Annual Scientific-Technical Collection - Mining of Mineral Deposits, 169-172. https://doi.org/10.1201/b16354-29

34. Cheberiachko, S., Yavors'ka, O., Radchuk, D., \& Yavorskyi, A. (2018). Respiratory Protection Provided by Negative Pressure Half Mask Filtering Respirators in Coal Mines. Solid State Phenomena, (277), 232-240. https://doi.org/10.4028/www.scientific.net/ssp.277.232

35. Buzylo, V., Pavlychenko, A., Savelieva, T., \& Borysovska, O. (2018). Ecological aspects of managing the stressed-deformed state of the mountain massif during the development of multiple coal layers. E3S Web of Conferences, (60), 00013. https://doi.org/10.1051/e3sconf/20186000013

36. Vlasova, E., Kovalenko, V., Kotok, V., \& Vlasov, S. (2016). Research of the mechanism of formation and properties of tripolyphosphate coating on the steel basis. Eastern-European Journal of Enterprise Technologies, 5(5(83)), 33-39. https://doi.org/10.15587/1729$\underline{4061.2016 .79559}$

37. Pivnyak, G., Beshta, A., \& Balakhontsev, A. (2010). Efficiency of water supply regulation principles. New Techniques and Technologies in Mining, 1-7. https://doi.org/10.1201/b11329-2

38. Volkov, A.V. (2002). Analysis of electromagnetic processes and improvement of active filter regulation. Elektrotekhnika, (12), 12-16.

39. Beshta, O.S. (2012). Electric drives adjustment for improvement of energy efficiency of technological processes. Naukovyi Visnyk Natsionalnoho Hirnychoho Universytetu, (4), 98-107.

40. Abdiev A., Mambetova, R., Abdiev, A., \& Abdiev S. (2020). Development of methods for assessing the mine workings stability. E3S Web of Conference. Preprint.

41. Nazarova, E.S. (2013). On the question of the development of diagnostic systems of electromechanical systems of cold rolling mills. Electrical Engineering and Power Engineering, (1), 82-89. https://doi.org/10.15588/1607-6761-2013-1-6

42. Mikhlin, Y. V., \& Zhupiev, A. L. (1997). An application of the ince algebraization to the stability of non-linear normal vibration modes. International Journal of Non-Linear Mechanics, 32(2), 393-409. https://doi.org/10.1016/s0020-7462(96)00047-9

43. Osadchyy, V.V., Nazarova, E.S., \& Brylistyy, V.V. (2019) Control System Structure of the 4th Drive Power Installations. Problemele Energeticii Regionale, 1-2(41), 65-73. https://doi.org/10.5281/zenodo.3239150 